\title{
Poland in the Driving Seat: A Mature Presidency in Turbulent Times
}

Citation for published version (APA):

Pomorska, K., \& Vanhoonacker, S. M. R. L. (2012). Poland in the Driving Seat: A Mature Presidency in Turbulent Times. Journal of Common Market Studies, 50(s2), 76-84. https://doi.org/10.1111/j.1468-

5965.2012.02276.x

Document status and date:

Published: 01/09/2012

DOI:

10.1111/j.1468-5965.2012.02276.x

Document Version:

Publisher's PDF, also known as Version of record

Document license:

Taverne

Please check the document version of this publication:

- A submitted manuscript is the version of the article upon submission and before peer-review. There can be important differences between the submitted version and the official published version of record.

People interested in the research are advised to contact the author for the final version of the publication, or visit the DOI to the publisher's website.

- The final author version and the galley proof are versions of the publication after peer review.

- The final published version features the final layout of the paper including the volume, issue and page numbers.

Link to publication

\footnotetext{
General rights rights.

- You may freely distribute the URL identifying the publication in the public portal. please follow below link for the End User Agreement:

www.umlib.nl/taverne-license

Take down policy

If you believe that this document breaches copyright please contact us at:

repository@maastrichtuniversity.nl

providing details and we will investigate your claim.
}

Copyright and moral rights for the publications made accessible in the public portal are retained by the authors and/or other copyright owners and it is a condition of accessing publications that users recognise and abide by the legal requirements associated with these

- Users may download and print one copy of any publication from the public portal for the purpose of private study or research.

- You may not further distribute the material or use it for any profit-making activity or commercial gain

If the publication is distributed under the terms of Article $25 \mathrm{fa}$ of the Dutch Copyright Act, indicated by the "Taverne" license above, 


\title{
Poland in the Driving Seat: A Mature Presidency in Turbulent Times
}

\author{
KAROLINA POMORSKA and SOPHIE VANHOONACKER \\ University of Maastricht
}

\section{Introduction}

In the second half of 2011, Poland held the rotating Presidency of the Council of the European Union for the first time. It took over from Hungary (see Ágh's contribution to this issue), another relative newcomer to the EU, and was part of the trio team together with its successors Denmark and Cyprus. Poland's high ambitions matched the selfperception of belonging to the 'big' Member States and the full commitment among the administrative and political elites to make their period at the helm a success. The financial means made available were considerable, as the budget amounted to around $€ 100$ million - two or three times more than some of the previous and subsequent Presidencies. Nonetheless, the forthcoming Presidency raised some eyebrows in Brussels as the memories of Poland as a troublemaker were still alive. The frequently unconstructive position during the Law and Justice (PiS)-led government (2005-07) (see Copsey and Pomorska, 2010 ) or the veto on reduction of $\mathrm{CO}_{2}$ emissions in June 2011 gave reasons for concern about potentially unpredictable behaviour.

Poland, however, proved to be a quick learner in the EU. In spite of the euro crisis, its economy was performing well (see Connolly in this issue), and was frequently compared in the media to a 'green island' of growth in Europe. ${ }^{1}$ Yet, some doubts persisted as to whether the high ambition would not stand in the way of achieving consensus and final success. Although the pro-European liberal conservative Civic Platform (PO) led the government, the prospect of parliamentary elections in the midst of the Presidency and a possible return to power of the Eurosceptic PiS loomed in the background. The Presidency posed some serious challenges for the administration and the government - among others were those related to the logistical capacity to manage responsibilities on such a scale, act as a broker and, in the words of a high-level official, 'to think beyond one's national interest'. ${ }^{2}$

The institutional set-up after Lisbon has also limited the roles and potential impact of the country at the helm of the Council (Dinan, 2010). The prime minister is no longer in the chair of the European Council, which now has its own permanent President. Thus, the media shots from the meeting of heads of state and government in December 2011 featured predominantly Herman Van Rompuy and the leaders of the 'Big Three', with the Polish prime minister, Donald Tusk, somewhat in the background. In terms of the financial crisis, as a non-member of the single currency Poland had not managed to secure

\footnotetext{
${ }^{1}$ Apparently, the term was coined after one of the prime minister's speeches was accompanied by a map of economic growth in Europe with most of the countries in red and Poland in green. See, for example, New York Times, 6 December 2010; The Observer, 19 February 2012; Świeboda, 2010.

${ }^{2}$ Interview at the Ministry of Foreign Affairs, Warsaw, 20 December 2011.
} 
the right to participate in the meetings of the Eurogroup. In addition, a great share of the foreign policy work was shifted to the High Representative for Foreign Affairs and Security Policy (HR) and the European External Action Service (EEAS). Under Lisbon, it was no longer the rotating Presidency but HR Catherine Ashton and her EEAS staff who chaired the common foreign and security policy (CFSP) meetings and represented the Union (see, for example, Missiroli, 2010; Vanhoonacker et al., 2010, 2012).

Still, the arrival of Van Rompuy and Ashton does not mean that the rotating Presidency has become irrelevant. One can even argue that it has become more pivotal than ever for the smooth running of the EU legislative machine. The further extension of co-decision and the Presidency's central role in interacting with an increasingly assertive European Parliament (EP) means that it continues to carry salient responsibilities in the day-to-day EU policy-making process as organizer, broker and even political leader (Schout and Vanhoonacker, 2006). In a union of 27 Member States and with the EP playing its co-legislative role to the full, the broker role of forging compromises and building bridges is more important than ever. Providing leadership post-Lisbon undoubtedly becomes more difficult, especially in the area of foreign affairs. However, as we will show in this article, this does not mean that the rotating Presidency no longer has the scope to prioritize dossiers or to try to steer the Union in a certain direction.

The article analyzes and evaluates the achievements of the Polish Presidency. It starts by presenting its priorities and examines its major accomplishments. Special attention is given to how the Polish Presidency dealt with crisis situations such as the economic, financial and sovereign debt crisis. The last section evaluates the Presidency's main achievements and investigates its performance with regard to its three key roles of organizer, broker and political leader. We will argue that even though the Poles performed quite well, despite the unfavourable circumstances, their success has gone largely unnoticed by the international public.

\section{From Financial Crisis to the Crisis of Trust}

An important test for the performance of the Presidency is its capacity to handle crisis situations (Dehousse and Menon, 2009). Very often the source of the crisis is external, but in the case of Poland the challenges came from within the EU itself. The financial, economic and sovereign debt crisis not only threatened Europe's economic well-being, but also raised challenges for the future of the EU. Commission President Barroso spoke of the 'most difficult period since European integration started' ${ }^{3}$ and Polish Prime Minister Donald Tusk proclaimed a 'crisis of trust' (Tusk, 2011b). Among the hotly debated topics was solidarity between the Member States, the (un)desirability of big Member States acting as the sole leaders in the integration processes and the more general aims of the integration, including possible closer union.

Although it was handicapped by its non-membership of the eurozone, Poland nevertheless managed to play a meaningful role. The co-ordination between the European Council, the Eurogroup and Ecofin went smoothly - not least thanks to the efforts and good personal contacts of the Finance Minister Jacek Rostowski. Poland contributed positively to finalizing the Six Pack negotiations on financial regulations by forging an

\footnotetext{
${ }^{3}$ EUobserver, 14 December 2011.
} 
agreement on some of the most sensitive issues. It managed to put the crisis in a broader perspective and made it very clear that the response was not less, but 'more Europe', as outlined in the inaugural speech of Prime Minister Tusk in the EP (Tusk, 2011a).

The message was echoed in a rather dramatic speech of Foreign Minister Sikorski in November 2011 in Berlin (Sikorski, 2011). Arguably, this was the only moment when the Presidency attracted wide media attention and sparked debate. Referring to the successful examples of the United States and Switzerland, Sikorski pleaded for nothing less than a European federation, based on a further strengthening of the European institutions, including a merger of the posts of the Presidents of the European Council and the European Commission. He advocated even the direct election of the President by the European demos. Warning that Europe was standing at the brink of a disaster, he spoke strongly in favour of active leadership of its western neighbour: 'I will probably be first Polish foreign minister in history to say so, but here it is: I fear German power less than I am beginning to fear German inactivity' (Sikorski, 2011). ${ }^{4}$ The speech was a clear expression of the Polish desire to be part of the European core and also an illustration of how Poland, since its accession in 2004, has increasingly been turning towards the EU rather than the United States, with Germany becoming its major partner. The declaration did not go unnoticed at home, where despite general praise it received some fierce criticism from PiS politicians.

Unfortunately, the ambitions expressed by Sikorski contrasted strongly with the reality on the ground. The players who really mattered in the negotiations with Greece and in the development of new and more stringent fiscal rules were German Chancellor Merkel and French President Sarkozy. As a non-member of the eurozone, there were clear limits to the scope of action by the Polish chair.

\section{Presidency Priorities}

Officially, the Polish Presidency announced three general priorities: European integration as a source of growth, a 'Secure Europe' and 'Europe Benefiting from Openness' (MFA, 2011a). Within these goals, there was strong emphasis on the further development of the Eastern Partnership (EaP) - a flagship initiative and potential source of prestige for the Foreign Ministry under Sikorski, who is a heavyweight in the Polish government. Since it is impossible to give a full account of the many dossiers covered, we limit ourselves to some of the most important ones, including economic growth, external relations, and climate, energy and defence.

\section{Economic Growth}

Every Presidency has the responsibility to press forward towards the achievement of the EU 2020 growth agenda. In the face of the financial crisis, the Polish Presidency decided to focus on negotiations over the new financial perspective (2014-20) and deepening the internal market. In the negotiations over the first issue, the Presidency played a minor role as the most important part of the process only took off after the Presidency finished. The fact that the European Commission proposal was kept intact as the basis for negotiations

\footnotetext{
${ }^{4} \mathrm{He}$ added quickly that Polish support was nonetheless conditioned upon Poland being included in the decision-making process.
} 
was generally considered a success (Tokarski and Toporowski, 2012). Poland was also praised for the smooth and timely adoption of the yearly EU budget (Nowak, 2012, p. 12). It was the first time since the entry into force of the new Treaty that the Council and the EP reached an agreement on the annual budget within the time provided by law (MFA, 2011c). Polish officials are also proud of the adoption of the so-called 'Six Pack' - a bundle of six legislative measures aimed at bringing more discipline to the finances of the Member States. It is often mentioned as one of the greatest achievements of the Presidency, but a large part of the work was conducted already by the Hungarians (see Ágh in this issue). A better example of where the Polish Presidency mattered, with the invaluable support of the Polish EP President Buzek, is the agreement with the EP on the so-called 'correlation tables'. Even though a great success, it was met with little publicity. The agreement aims at facilitating the implementation of EU legislation by providing links between the provisions in EU directives and the corresponding rules in the Member States. Poland also managed to finalize eight second-reading agreements, ${ }^{5}$ including two of high importance: the so-called 'WEEE dossier' on electronic waste and electrical equipment, ${ }^{6}$ and one on biocidal products.

On a less positive note, Poland presented a report entitled Towards a European Consensus on Growth (MFA, 2011b), which was criticized for its disappointing analytical angle and lack of innovative ideas, but praised as a political instrument to encourage politicians to think long term (Eada and Kucharczyk, 2012). With regard to the internal market, the main achievement was settling a 30-year long dispute and securing agreement over the single EU Patent, with the creation of the Unitary Patent Court and a system of patent protection. The lack of an intergovernmental agreement over the location of the central patent court (with London, Paris and Munich in the running) added a bitter note to the celebrations and meant that the process was brought to a halt. At the time of writing, the EP had not voted on its position and the Council had not yet adopted the necessary texts.

\section{External Relations}

As mentioned above, in the area of external relations, Poland had been stripped of most of the previous Presidencies' prerogatives that were now given to the High Representative Ashton and the EEAS. While possible clashes between an ambitious foreign minister and the HR were to be expected, Sikorski was quick to kill these concerns by announcing that he would be Ashton's 'loyal deputy'. ${ }^{8}$ Indeed, the two soon found a common language and agreed on a division of representative duties. Sikorski, for example, represented the EU in Libya, the Foreign Affairs Committee in the EP, and at a meeting with Uzbekistan. The relations with the EEAS gradually took shape, with Polish officials reporting an increase in trust and co-operation as the Presidency proceeded. Polish embassies represented the EU in 12 third countries without EU delegations. Tensions emerged, however, in places where the Presidency coexisted with the EU delegations, especially regarding consular affairs and the lack of the exact division of competences on the ground.

\footnotetext{
${ }^{5}$ This included three second-reading agreements and five early second-reading agreements.

${ }^{6}$ Proposal for a Directive of the European Parliament and of the Council on waste electrical and electronic equipment (WEEE) (recast) (2008/0241 COD).

${ }^{7}$ Proposal for a regulation of the European Parliament and of the Council concerning the placing on the market and use of biocidal products (2009/0076 COD).

${ }^{8}$ EUobserver, 2 July 2011.
} 
An interesting novelty for the Polish Presidency was the fact that for the first time there were several cases of co-decision in the realm of external relations. It concerned the establishment of financing instruments for development co-operation, promotion of democratic and human rights, and for co-operation with industrialized countries. Poland, and especially the chair of the Committee of Permanent Representatives (Coreper II), played a positive role here, investing time and efforts into establishing good relations with the EP.

While the most visible events in the international media were the ongoing revolutions in North Africa, Warsaw devoted most of its efforts and attention to the development of the EaP initiative. Since becoming a member of the EU in 2004, Poland has continuously lobbied within the Council for establishing a more proactive policy towards the EU's eastern neighbours. Supported by Sweden, these efforts were finally rewarded with the inauguration of the EaP in 2009. However, by the time Poland took over the Presidency, the initiative was being criticized for lacking substance and tangible results. In addition, the political situation in the targeted countries was deteriorating in terms of democratic standards. In response, Poland called for the establishment of the European Endowment for Democracy (finalized with a declaration in December) as an instrument to support civil society, media and even political actors in third countries. At the same time, efforts were made to mark the Polish presence in North Africa - for example, with the declarations to share lessons learned from Poland's experience of transition to democracy.

A further landmark event was the EaP summit organized at the end of September in Warsaw. The main results included a long-term commitment to waiving the visas of the partnership countries and the establishment of the Eastern Partnership Academy in Warsaw (European Council, 2011a). Unfortunately, the summit ended with disunity between the Member States and the neighbouring countries regarding the final declaration condemning the political situation in Belarus. Some internal commentators even called it the biggest failure of the Presidency and the de facto breakdown of the EU's eastern policy, 'as evidenced by Poland and the Union's helplessness towards the Lukashenko regime in Belarus and the Yulia Tymoshenko show-trial in Ukraine'.?

The end of the Presidency was marked by the signing of the Accession Treaty with Croatia and a summit with Ukraine. The arrest of Yulia Tymoshenko made it difficult for Poland to champion the Ukrainian case within the EU, but the substantive part of the negotiations over the Association Agreement were completed, including the establishment of the Deep and Comprehensive Free Trade Area (DCFTA). Nonetheless, the Union postponed the initialling of the agreement until spring 2012, and the signing and eventual ratification of the agreement until after the Ukrainian elections scheduled for autumn 2012. The Council also agreed on negotiation mandates on the visa facilitation and readmission agreements with Armenia and Azerbaijan.

\section{Energy Security, Climate and Defence}

The third section of the Presidency programme on European security included areas as diverse as food, energy and defence. It was no surprise to find the external energy policy of the Union, including a new energy strategy, among the priorities of the Presidency. This had been a sensitive topic for Poland, especially in the context of the EU's relations with

\footnotetext{
${ }^{9}$ Presseurop, 15 December 2011.
} 
Russia. Equally unsurprising was the absence of climate policy, which has a significant impact on Polish energy policy and as Poland opposes raising the 2020 emission reduction targets (for more, see Spencer et al., 2011). The Polish veto with regards to the limiting of $\mathrm{CO}_{2}$ emissions in June 2011 was not the best start to the Presidency. Subsequently, Polish performance during the climate conference in Durban (November-December 2011) prompted some unfavourable comments, including the reminder that Polish diplomats 'ought to speak in the voice of Europe, not Poland' (Karaczun, 2012). Overall, in the realm of energy security, the results were mixed. On the positive side, Poland managed to push for the Council Conclusions of November 2011 to focus on external energy security (European Council, 2011b). In addition, the European Commission was given a mandate to negotiate an agreement with Turkmenistan and Azerbaijan on the legal framework for the Trans-Caspian Gas Pipeline System. On the negative side, the Commission was not granted control over the external security deals.

In the field of internal security, the scale of ambitions was trimmed down as the Presidency drew closer. In the end, it was 'just' border protection and homeland security that found their way into the official Presidency programme. One of the main achievements in this domain was securing agreement over the European Protection Order (EPO), which lays down that victims of crime that have been granted protection from their aggressors in one EU Member State will also get such protection in another EU country.

When it comes to CSDP which was scaled down on the list of priorities, Poland did not manage to strike any groundbreaking deals. Ideological divisions between the Member States were too wide to be bridged. Some small steps were achieved, such as installing a Brussels-based EU Civil-Military Operations Centre for the Horn of Africa. The European Defence Agency agreed to start 12 so-called 'pooling and sharing projects', including, for example, helicopter pilot training, maritime surveillance network, naval training and logistics, air-to-air fuelling and smart munitions. Overall, however, no substantial progress was achieved in this area.

\section{Evaluating the Polish Presidency in Its Different Roles}

Following the overview of the Presidency aims and the principal dossiers on the agenda, we will now assess the Polish performance through the lenses of the different roles of organizer, broker and political leader. As mentioned before, the Lisbon Treaty has affected these roles, and in the case of political leadership, reduced the Presidency's room for manoeuvre. Still, we argue that there remains sufficient scope for fulfilling each of them.

As chair of all Council formations with the exception of the Foreign Affairs Council (FAC), the Presidency continued to face important logistical challenges, which it fulfilled in close co-operation with the Council General Secretariat. Broadly speaking, Poland did very well in its capacity of an organizer. The administration was overall well-prepared to carry the everyday burdens of the Presidency. Preparations were ongoing for three-anda-half years, including language courses for the government officials. ${ }^{10}$ In the absence of previous experience, lessons had to be learned from others and Polish officials were particularly grateful for the help they received from their Swedish colleagues. Prior to their period at the helm, the informal Presidency Team 'task force' toured the Member

\footnotetext{
${ }^{10}$ Interview at the Ministry of Foreign Affairs, Warsaw, 20 December 2011.
} 
States in search of the best institutional arrangements. The Permanent Representation in Brussels was reinforced and hosted approximately 300 officials and in total 452 meetings were organized. Besides the careful preparations and the investment in human and material resources, the smooth organization was furthermore fostered by the close co-operation with the Council General Secretariat. Contrary to some other (often big) Member States, Poland did not make the mistake of reinventing the logistical wheel, but rather relied on the highly experienced Secretariat for the organization of the multiple meetings and diffusion of documents.

Second, Poland performed well, but not outstandingly, as a broker. The Presidency not only managed to strike numerous deals within the Council, but was also successful in its interactions with the other institutions, especially with the EP. One has to remember that when Poland took over the Presidency, there was a lot of tension between the Council and the Parliament, now further empowered by the Lisbon Treaty. Some of the biggest successes were the agreement on the correlation tables, the Six Pack, the single EU patent and the EPO. As often is the case, all of these initiatives were already ongoing under previous Presidencies, allowing Poland to build on earlier breakthroughs. The fact that Jerzy Buzek, a Polish national, was the President of the EP was an asset for a Presidency so highly dependent on its co-legislator to achieve results.

One shadow hanging over the Polish mediating role was that the scope for scoring was curtailed due to the high number of dossiers already concluded under its Hungarian predecessor. According to some, this led to the Presidency in Coreper I 'to pull' dossiers from the lower levels, unnecessarily discussing technicalities and departing from the mostly political negotiations at this level. ${ }^{11}$ Finally, the small Member States may have felt at times excluded from the Presidency's consultations and the information loop. Despite its efforts, Poland did not manage to achieve agreement regarding Bulgaria and Romania joining the Schengen zone. This was in the first place due to the intransigence of Finland as well as the Dutch government, held hostage by the Freedom Party of Wilders. The EU Affairs Minister called this the 'biggest disappointment of the Presidency'. ${ }^{12}$

Finally, we come to the political leadership question. It is clear that as a non-member of the eurozone, there was little room for a Polish leadership role in the sovereign debt crisis. Here, the initiative was taken by the French President Sarkozy and the German Chancellor Merkel, supported by Herman Van Rompuy as chair of the European Council. As said before, the role of Poland was more of a co-ordinating nature. As a non-eurozone Presidency, it can, however, claim credit for selling the case for a generalization of fiscal discipline beyond the eurozone and making the fiscal treaty as inclusive as possible.

The dossier where Poland was the most active in steering the EU in a particular direction is the boost it gave to the Eastern Partnership initiative. It could do so thanks to its long-standing expertise in the field and co-operation with other partners such as Sweden. The efforts led to concrete results such as the European Endowment for Democracy and the Eastern Partnership Academy. At the same time, the case also illustrates the limits of what a rotating Presidency can do in a period of six months. The political crisis in Belarus and the arrest of Tymoshenko in Ukraine prevented Poland from fully realizing its ambitions.

\footnotetext{
${ }^{11}$ Interview by the authors, May 2012.

${ }^{12}$ EurActiv, 16 December 2011.
} 


\section{Conclusions}

The Polish Presidency was well organized and, in most cases, proved that it could think beyond its own national interest. In addition, it took the opportunity to further shape its profile as exporter of democracy to the east and to the south. Not surprisingly, Poland received multiple compliments for its performance both from its peers as well as from the press. Pointing to Poland's high level of professionalism in very turbulent times, the leader of the centre-left Socialists and Democrats in the EP Martin Schultz went as far as praising the conservative Prime Minister Tusk for leading what was 'without a doubt one of the very best presidencies we have ever had' ${ }^{13}$ Poland was clearly no longer the inexperienced and sometimes unreliable partner of the early years. It had developed from a country well-known for its Atlanticist predilections to a player that wanted to fully assume its responsibilities at the core of the EU. Still, except for those involved, the Polish performance passed largely unnoticed. While in the past it was at times of crisis when the Presidency used to catch the public eye, now it was exactly because of the crisis that the Poles remained in the shadows.

The period of the second half of 2011 was not only instructive about the changing Polish position in the EU, it was also illustrative of the altering role of the rotating Presidency. Poland was the fourth country at the helm under the new Lisbon regime. It was clear that while in the legislative processes the workload and responsibilities increased, not only within the Council but also vis-à-vis the EP, in other domains the Presidency's room for manoeuvre has been considerably reduced. Any action in the field of foreign policy requires careful co-ordination with the HR, while at the level of the European Council it is now clearly the big Member States, in interaction with Van Rompuy, who set the tone. The Poles themselves seem to be rather conscious of the limits of the rotating chair. It may be partly attributed to insufficient public diplomacy, but 53 per cent of respondents to the nationwide opinion poll thought that Poland 'did not achieve much' (CBOS, 2012), while 77 per cent stated that the Presidency did not matter as it was the biggest Member States who had most influence on the policies. In spite of this, 63 per cent believed the international image of Poland improved.

This internal perception that its period at the helm contributed positively to Poland's international - or at least European - reputation may be more than just wishful thinking. As a country, which after more than 40 years of communism chose radically for reintegration into the west, Poland took its Presidency very seriously. It invested in the preparations and the otherwise rather assertive Poles showed a remarkable openness to learn from more experienced predecessors. One of these lessons was that it was imperative to set a small number of clear and limited objectives and that, rather than pushing for its own interests, it was important to listen to others and to operate as a bridge builder.

\section{References}

CBOS (Public Opinion Research Centre) (2012) Evaluation of Polish Presidency of the Council of the European Union (Warsaw: CBOS). Available at: «http://www.cbos.pl/EN/publications/ reports/2012/011_12.pdf».

Copsey, N. and Pomorska, K (2010) 'Poland's Power and Influence in the European Union'. Comparative European Politics, Vol. 8, No. 3, pp. 304-26.

${ }^{13}$ EUobserver, 14 December 2011.

C 2012 The Author(s) JCMS: Journal of Common Market Studies @ 2012 Blackwell Publishing Ltd 
Dehousse, R. and Menon, A. (2009) 'The French Presidency'. JCMS, Vol. 47, No. S1, pp. 99-111.

Dinan, D. (2010) 'Institutions and Governance: A New Treaty, a Newly Elected Parliament and a New Commission'. JCMS, Vol. 48, No. S1, pp. 95-118.

European Council (2011a) 'Joint Declaration of the Eastern Partnership Summit', Warsaw, 29-30 September. Available at: «http://www.consilium.europa.eu/uedocs/cms_Data/docs/pressdata/ en/ec/124843.pdf».

European Council (2011b) 'Communication on Security of Energy Supply and International Cooperation: 'The EU Energy Policy: Engaging with Partners beyond Our Borders', Brussels, 25 November.

Karaczun, Z. (2012) Reflections on the Polish Presidency of the Council of the European Union: Climate and Energy (Berlin: Heinrch Boll Stiftung). Available at: «http://www.boell.eu/web/ 270-803.html».

Łada, A. and Kucharczyk, J. (2012) Pole Position: The Polish Presidency of the Council (Warsaw: ISP). Available at: «http://www.isp.org.pl/aktualnosci,1,927.html».

Ministry of Foreign Affairs (MFA) (2011a) Programme of the Polish Presidency of the Council of the European Union (Warsaw: MFA). Available at: «http://www.pl2011.eu».

Ministry of Foreign Affairs (MFA) (2011b) Towards a European Consensus on Growth: Report of the Polish Presidency of the Council of the European Union (Warsaw: MFA). Available at: «http://www.mg.gov.pl/files/upload/14718/5-Raport_wersja\%20angielska.pdf».

Ministry of Foreign Affairs (MFA) (2011c) 'Major Results of the Work of the Polish Presidency of the European Union Council'. Press Release, 22 December. Available at: «http://pl2011.eu/ sites/default/files/users/shared/spotkania_i_wydarzenia/osiagniecia_en.pdf».

Missiroli, A. (2010) 'The New EU "Foreign Policy" System after Lisbon: A Work in Progress'. European Foreign Affairs Review, Vol. 15, No. 4, pp. 427-52.

Nowak, B. (2012) 'Ostatnia prezydencja dużych oczekiwań - refleksje po Prezydencji Polski w Radzie UE'. In Raporty i Analizy Centrum Stosunków Międzynarodowych (Warsaw: CSM).

Schout, A. and Vanhoonacker, S. (2006) 'Evaluating Presidencies of the Council of the EU: Revisiting Nice'. JCMS, Vol. 44, No. 5, pp. 1051-77.

Sikorski, R. (2011) 'Poland and the Future of the European Union'. Speech delivered in Berlin, 28 November. Available at: «http://www.msz.gov.pl/files/docs/komunikaty/20111128BERLIN/ radoslaw_sikorski_poland_and_the_future_of_the_eu.pdf».

Spencer, T. et al. (2011) 'Linking an EU Emission Reduction Target Beyond 20\% to Energy Security in Central and Eastern Europe'. FIIA Working Paper 16, March (Helsinki: Finnish Institute of International Affairs).

Świeboda, P. (2010) 'Poland: Island of Stability in the European Sea of Trouble', demosEuropa. Available at: «http://www.demoseuropa.eu/index.php?option=com_content\&view=article\&id= 482\&Itemid=104».

Tokarski, P. and Toporowski, P. (2012) 'The EU Budgetary Chess Game, the Polish Presidency and the Shadows of the Debt Crisis'. PISM Policy Paper 26 (Warsaw: Polish Institute of International Affairs).

Tusk, D. (2011a) 'Prime Minister Donald Tusk's Address on the Polish Presidency in the EU in the European Parliament', Brussels, 6 July.

Tusk, D. (2011b) 'Prime Minister Donald Tusk's Address to the European Parliament to Conclude the Polish Presidency in the EU', Strasbourg, 14 December.

Vanhoonacker, S., Pomorska, K. and Maurer, H. (2010) The Council Presidency and European Foreign Policy: Challenges for Poland in 2011 (Warsaw: CSM).

Vanhoonacker, S., Pomorska, K. and Petrov, P. (eds) (2012) 'The Emerging EU Diplomatic System'. Special issue of the Hague Journal of Diplomacy, Vol. 7, No. 1. 